\title{
Epilepsie en taalproblemen
}

Bij patiënten met epilepsie kan een algemene cognitieve functie zoals de mentale verwerkingssnelheid aangedaan zijn, maar ook selectief één of enkele specifieke cognitieve domeinen. Zo komen er ook problemen met taal en aanverwante functies voor bij volwassenen met epilepsie. Deze taalproblemen kunnen een gevolg zijn van de epilepsie zelf, maar ook van de behandeling met anti-epileptica of het gevolg van epilepsiechirurgie. In deze bijdrage een kort overzicht van taalproblemen bij volwassen patiënten met epilepsie.

\section{Om wellke taalproblemen gaat het?}

Het onderzoek naar taalproblemen heeft zich vooral beperkt tot patiënten met temporaalkwabepilepsie. Een schatting van het totaal aantal patiënten dat bij de epilepsie taalproblemen heeft is daarom niet mogelijk. Volgens de beschikbare data heeft ten minste $17 \%$ van de patiënten met epilepsie op de een of andere manier moeite met taal. Het meest voorkomend is een probleem met woordvinding, hetgeen een negatief effect heeft op de spontane spraak. Daarnaast worden ook lichte problemen bij begrijpend lezen en het beknopt onder woorden brengen van gedachten gerapporteerd (Bartha-Doering \& Trinka, 2014). Een compleet beeld is moeilijk te geven omdat de meeste onderzoeken slechts een deel van de taalfuncties hebben bestudeerd. Verder vinden sommige onderzoekers wél significante verschillen tussen epilepsiepatiënten en gezonde controles, waar deze in andere onderzoeken niet significant verschillend zijn. Dit kan het gevolg zijn van populatie selectie (bij een te heterogene groep of een homogene groep zonder problemen) en van test selectie waardoor eventuele afwijkingen worden gemist.

\section{Taalproblemen ten gevolge van de epilepsie}

De hierboven genoemde taalproblemen zijn hoofdzakelijk aangetoond bij patiënten met temporaalkwabepilepsie. Er zijn duidelijke correlaties gevonden met de aanwezigheid van een afwijking aangetoond door beeldvorming. $\mathrm{Zo}$ is er een verband tussen slechtere woordvinding en hippocampale sclerose. Naast studies bij patiënten met een temporaal focus is er één studie bij patiënten met frontaalkwabepilepsie gedaan, die vergelijkbare problemen met woordvinding beschrijft. Ook bij patiënten met gegeneraliseerde epilepsie kan het woordvinden aangedaan zijn (Bartha-Doering \& Trinka, 20I4). Bij al deze patiënten wordt de epilepsie (zij het soms ten dele) als oorzaak van het taalprobleem gezien. Hierbij dient opgemerkt te worden dat het hier zonder uitzondering cross-sectionele studies betreft, waardoor causaliteit niet te bewijzen is. Uit onderzoek met functionele MRI (FMRI) is bekend dat bij patiënten met taalproblemen de connectiviteit binnen hun taalnetwerk is afgenomen, terwijl er geen duidelijke afname is van de activatie in één van de taalgebieden (Vlooswijk et al., 20Io). Dit past goed bij het huidige concept van epilepsie als netwerkaandoening (Vlooswijk et al., 2017). Door de epilepsie kan (of wellicht: moet) het taalnetwerk zich anders organiseren. Zo is het mogelijk dat bij een vroeg optredende epilepsie vanuit de linker hemisfeer een verplaatsing optreedt van (een deel van) de taalfuncties naar de rechter hemisfeer (Balter et al., 2016). De reorganisatie van taalnetwerken als gevolg van epilepsie die op latere leeftijd optreedt kan anders zijn. Reorganisatie van taalnetwerken, waarbij een bilaterale representatie van taal ook een uitkomst kan zijn, leidt echter in alle gevallen tot minder goede scores op de testen voor taal en daarmee in meer of mindere mate tot taalproblemen (Bartha-Doering \& Trinka, 20I4).

\section{Taalproblemen ten gevolge van medicatie}

Cognitieve effecten als gevolg van het gebruik van antiepileptica betreffen doorgaans de fluïde cognitieve functies, zoals aandacht en mentale snelheid (IIff \& Aldenkamp, 2013). Topiramaat kan echter selectief taalproblemen veroorzaken, variërend van teruggang in de taalontwikkeling bij kinderen tot niet-vloeiende spraak met woordvindingsstoornissen bij volwassenen (Donegan et al., 2015; IIff \& Aldenkamp, 2013). In een taakspecifieke fMRI-studie waarin patiënten die topiramaat gebruikten werden vergeleken met patiënten die levetiracetam gebruikten werd bij de eerste groep een verminderde activatie in de frontale en pariëtale netwerken en een afgenomen deactivatie in netwerken die normaal gesproken worden gedeactiveerd vastgesteld (Wandschneider et al., 20I7). De taalproblemen bij gebruik van topiramaat zijn echter reversibel, het vervangen of staken van de behandeling leidt tot herstel van de taalfuncties.

\section{Taalproblemen na een invasieve ingreep}

Preoperatief onderzoek is gericht op het voorkomen van 
neurologische uitvalsverschijnselen als gevolg van operatie. Taal is een belangrijke functie die ongeschonden dient te blijven. Afhankelijk van de voorgenomen operatie wordt naast het standaard uitgebreide neuropsychologisch onderzoek een taalspecifieke fMRI, een Wada-test of directe corticale stimulatie gebruikt om enerzijds de lateralisatie van taal en het verbale geheugen te bepalen en anderzijds de specifieke plaats van de bij taal betrokken gebieden in kaart te brengen (corticale mapping met stimulatie). Ondanks deze procedures kunnen patiënten na de operatie last hebben van verminderde cognitieve functies, zoals verminderd verbaal geheugen en minder vloeiend taalgebruik, vooral na resecties in de linker temporaalkwab (Helmstaedter, 2013). Behalve een resectie kan ook het preoperatief invasief onderzoek, waarbij diepte-elektroden worden geïmplanteerd in de hippocampi, leiden tot achteruitgang van het verbale geheugen. In een studie waarbij bij zestien patiënten een diepte-electrode in de linker hippocampus was geïmplanteerd, ging bij 56\% van de patiënten het verbale geheugen achteruit. In de controlegroep gebeurde dat slechts bij 2r\% (Ljung et al., 2017). Deze studie kent weliswaar methodologische tekortkomingen, zoals een retrospectieve studieopzet en daarmee een gebrek aan homogeniteit in patiëntpopulatie en follow-up, maar met het gegeven dat een diepte-elektrode niet geheel schadeloos ingebracht kan worden in de hippocampus dient rekening gehouden te worden.

\section{Conclusies}

Taalproblemen, met name problemen met woordvinding en het verbaal geheugen, komen frequent voor bij patiënten met epilepsie. Soms is de oorzaak van een taalprobleem de medicamenteuze behandeling (denk aan topiramaat). Meestal is de oorzaak echter de epilepsie (of de onderliggende pathologie die de epilepsie veroorzaakt) en is het moeilijk te ontrafelen of er een samenhang is tussen de taalproblemen en de medicatie of een andere toegepaste behandeling. Bij invasieve onderzoeken en behandelingen dient steeds afgewogen te worden of het risico op cogni- tieve stoornissen (en taalproblemen) opweegt tegen de ernst en lijdenslast ten gevolge van de epilepsie enerzijds en het risico op cognitieve verslechtering door de epilepsie zonder verdere behandeling anderzijds. Dit is bij uitstek een afweging die behandelaars in samenspraak met een patiënt kunnen maken.

\section{Referenties}

Balter S, Lin G, Leyden KM, Paul BM, McDonald CR (20I6) Neuroimaging correlates of language network impairment and reorganization in temporal lobe epilepsy. Brain Lang. doi:10.1016/j.bandl.2016.06.002 Bartha-Doering L, Trinka E (2014) The interictal language profile in adult epilepsy. Epilepsia 55(10);1512-1525.

Donegan, S., Dixon, P, Hemming K, Tudur-Smith C, Marson A (2015) A systematic review of placebo-controlled trials of topiramate: How useful is a multipleindications review for evaluating the adverse events of an antiepileptic drug? Epilepsia 56(12);1910-1920.

Helmstaedter C (2013) Cognitive outcomes of different surgical approaches in temporal lobe epilepsy. Epileptic Disord. 15(3);221-239. doi:10.1684/epd.2013.0587

IJff DM, Aldenkamp AP (2013) Cognitive side-effects of antiepileptic drugs in children. Handb Clin Neurol. 111;707-718.

Ljung H, Nordlund A, Strandberg M, Bengzon J, Kallen K (2017) Verbal memory decline from hippocampal depth electrodes in temporal lobe surgery for epilepsy.

Epilepsia 58(12);2143-2152

Vlooswijk MC, Jansen JF, Majoie HJ, Hofman PA, de Krom MC, Aldenkamp AP, Backes WH (2010) Functional connectivity and language impairment in cryptogenic localization-related epilepsy. Neurology 75(5);395-402.

Vlooswijk MCG, Rouhl RPW, IJff D (2017) Epilepsie en cognitie: Meer aandacht voor epilepsie als netwerkaandoening. Epilepsie, periodiek voor professionals 15(1);10-12.

Wandschneider B, Burdett J, Townsend L, et al. (2017) Effect of topiramate and zonisamide on fmri cognitive networks. Neurology 88(I2);II65-II7I.

\author{
I8 januari 2019
}

Academisch Medisch Centrum | Meibergdreef 9, Amsterdam 